\title{
Penerapan Technology Acceptance Model (TAM) dalam Pengujian Model Penerimaan Aplikasi MasjidLink
}

\author{
(Application of Technology Acceptance Model (TAM) in Testing the Acceptance Model of Application \\ MasjidLink)
}

\section{Agus Mulyanto, Sumarsono, ThaQibul FiKRI NiYARTAMA, ANNISA KHODISTA SyAKA}

\section{ABSTRAK}

\begin{abstract}
MasjidLink merupakan aplikasi berbasis Android untuk memberikan berita dan informasi yang berkaitan dengan masjid-masjid di Daerah Istimewa Yogyakarta. Aplikasi MasjidLink saat ini adalah aplikasi manajemen informasi masjid yang baru diluncurkan dan mulai diterapkan oleh beberapa takmir masjid di Daerah Istimewa Yogyakarta. Penerimaan takmir terhadap aplikasi MasjidLink adalah salah satu faktor yang mendukung keberlangsungan penggunaan aplikasi tersebut. Pengukuran penerimaan takmir masjid terhadap aplikasi MasjidLink dilakukan dengan metode TAM (Technology Acceptance Model). Penelitian ini bertujuan untuk mengevaluasi penerapan aplikasi MasjidLink dengan metode TAM, sehingga persepsi takmir dan faktor-faktor yang mempengaruhi takmir dalam menggunakan aplikasi tersebut dapat diketahui. Metode penelitian yang digunakan adalah metode kuantitatif, yaitu menggunkan kuesioner sebagai alat untuk mengumpulkan data terhadap 125 pengguna aplikasi MasjidLink. Hasil penelitian menunjukan penerimaan takmir masjid terhadap aplikasi MasjidLink memiliki pengaruh positif pada 3 variabel TAM, yaitu persepsi kemudahan pengguna $72.68 \%$, persepsi kebermanfaatan $72.11 \%$, dan penerimaan teknologi $71.31 \%$. Hal ini menunjukan bahwa pengembang aplikasi dapat berfokus untuk meningkatkan pengembangan pada variabel penerimaan aplikasi MasjidLink karena nilai variabel persentasenya yang lebih kecil dibanding nilai variabel lainnya.
\end{abstract}

Kata Kunci: MasjidLink, Technology Acceptance Model, Persepsi kemudahan, Persepsi kebermanfaatan, Penerimaan teknologi informasi.

\section{ABSTRACT}

MasjidLink is an Android-based application to provide news and information relating to mosques in the Special Region of Yogyakarta. Currently, MasjidLink is a new mosque information management application that was launched and started to implemented by several takmir mosques in the Special Region of Yogyakarta. Takmir's acceptance of the MasjidLink application is one of the factors that support the continued use of the application. The measurement of the mosque takmir acceptance on the MasjidLink application is done by the TAM (Technology Acceptance Model) method. This study aims to evaluate the application of MasjidLink application with the TAM method so that the perception of takmir and the factors that influence takmir in using the application can be known. The research method used is a quantitative method, which uses a questionnaire as a tool to collect data on 125 users of the MasjidLink application. The results showed acceptance of mosque takmir on MasjidLink application had a positive influence on 3 TAM variables, namely the perception of user convenience $72.68 \%$, perceived usefulness of $72.11 \%$, and technology acceptance $71.31 \%$. This shows that the application developer can focus on improving the acceptance of the MasjidLink application variable because the variable percentage is smaller than other variables.

Keywords: MasjidLink, Technology Acceptance Model, Perceived Ease of Use, Perceived Usefulness, and Acceptance of Technology Information. 


\section{PENDAHULUAN}

MasjidLink merupakan aplikasi berbasis Android untuk memberikan berita dan informasi yang berkaitan dengan masjid-masjid di Daerah Istimewa Yogyakarta. Aplikasi ini akan menjadi sarana publikasi dan menunjang kegiatan manajemen masjid. Pengguna aplikasi MasjidLink adalah takmir masjid.

Aplikasi MasjidLink telah tersedia dan dapat diunduh di PlayStore, sehingga memudahkan pengguna untuk mengakses aplikasi MasjidLink. Aplikasi pada MasjidLink memiliki sembilan fungsi utama yaitu : manajemen masjid, manajemen profil takmir, manajemen agenda masjid, manajemen jadwal sholat jumat, manajemen data kurban masjid, manajemen kas masjid, manajemen akun, dan informasi berita masjid lain yang terdaftar.

Keberlangsungan pengguna untuk terus menggunakan suatu aplikasi merupakan tantangan tersendiri dalam lingkungan pengembangan. Keterlibatan pengguna yang aktif adalah salah satu proses pembangunan aplikasi. Tujuan keterlibatan pengguna dalam pengembangan aplikasi adalah memudahkan pengguna dalam menggunakan proses bisnis aplikasi tersebut. (Krisnawijaya and Dewi, 2019).

Aplikasi MasjidLink saat ini adalah aplikasi manajemen informasi masjid yang baru diluncurkan dan mulai diterapkan oleh beberapa takmir masjid di Daerah Istimewa Yogyakarta, sehingga belum pernah ditentukan tingkat penerimaan takmir terhadap aplikasi ini. Penerimaan takmir terhadap aplikasi MasjidLink merupakan salah satu faktor yang mendukung keberlangsungan penggunaan aplikasi tersebut. Pengukuran penerimaan takmir masjid dapat dilakukan dengan metode TAM (Technology Acceptance Model). Sehingga evaluasi penerimaan takmir terhadap aplikasi MasjidLink dalam penelitian ini akan menggunakan pendekatan TAM.

Penelitian ini bertujuan untuk mengetahui persepsi takmir masjid terhadap aplikasi MasjidLink serta melihat faktor-faktor yang dapat mempengaruhi takmir dalam menggunakan aplikasi ini.

Penelitian tentang pengujian TAM pada teknologi informasi sudah banyak dilakukan oleh penelitian lain. Salah satunya penelitian yang dilakukan oleh (Puspita, 2016) yaitu mengetahui sikap penerimaan civitas akademik di Universitas Lampung terhadap internet banking dengan TAM. Penelitian ini bertujuan untuk menguji TAM pada sikap penerimaan civitas akademik di Universitas Lampung terhadap internet banking. Penelitian ini menggunakan rancangan penelitian metode kuantitatif dan data primer yang diperoleh dari kuesioner. Simpulan yang dihasilkan dari penelitian ini adalah persepsi pengguna terhadap kemudahan dan kegunaan memiliki pengaruh signifikan dengan sikap penerimaan internet banking. Berdasarkan pengujian yang dilakukan penelitian ini maka didapatkan kesimpulan bahwa TAM dapat menjabarkan secara keseluruhan penerimaan internet banking.

Penelitian selanjutnya dilakukan oleh Ratri (2016). Penelitian ini menggunakan pendekatan TAM untuk menentukan elemen-elemen yang mempengaruhi Guru SMK Negeri 2 Yogyakarta dalam menggunakan E-Learning Moodle. Penelitian ini menggunakan jenis penelitian ex-post facto serta pendekatan kuantitatif. Data primer dalam penelitian ini diperoleh dari kuesioner. Hasil analisis dari penelitian ini adalah faktor-faktor yang berpengaruh terhadap penggunaan e-learning PINTER yaitu faktor e-learning self-efficancy, faktor kerumitan diketahui dengan beberapa faktor yaitu kegunaan, kemudahan pengguna, keinginan, kekurangan waktu baik secara sengaja maupun tidak sengaja.

Penelitian TAM selanjutnya dilakukan Napitupulu (2017) dalam menentukan sikap pengguna terhadap penerimaan sistem $e$ learning menggunakan variabel-variabel TAM. Tujuan penelitian ini adalah mengetahui gambaran keberhasilan penerapan e-learning berdasarkan penerimaan pengguna di lingkungan Universitas XYZ. Hasil penelitian berdasarkan data yang telah dikumpulkan dari 73 responden menunjukan bahwa pengguna setuju dengan nilai persentase kebermanfaatan sistem e-learning $69.12 \%$, kemudahan sistem $e$ learning $69.80 \%$, dan pengguna seluruhnya setuju dengan penerimaan sistem e-learning dengan $72.69 \%$.

Penelitian oleh (Hermawan, 2019) menggunakan metode TAM untuk menjelaskan perilaku penerimaan pengguna terhadap aplikasi parental control yang memiliki landasan kepercayaan (beliefs), sikap (attitude), 
minat (intention), dan hubungan perilaku antar pengguna teknologi (user behavior). Penggunaan metode ini bertujuan untuk menemukan faktor-faktor utama perilaku pengguna terhadap penerimaan penggunaan aplikasi parental control. Hasil penerapan metode TAM menunjukan bahwa penggunaan Screen Time (ST) dipengaruhi oleh variabel kebermanfaatan (usefulness) dan kemudahan (easy to use). Kedua variabel tersebut diperoleh dari determinan yang tinggi dan validitas yang telah diuji secara empiris.

Penelitian lainnya yang menggunakan metode TAM dilakukan oleh (Alvin and Kurniawati, 2019). Penelitian ini menganalisis penerimaan Auditor Eksternal terhadap Audit System yaitu CAATs (Computer Assisted Audit Techniques). Tujuan dari penelitian ini adalah mengetahui faktor-faktor penerimaan audit system tersebut terhadap auditor eksternal dengan menggunakan model TAM sehingga diharapkan dapat meningkatkan penggunaan CAATs di masa yang akan datang. Data penelitian yang digunakan adalah persepsi auditor eksternal di DKI Jakarta. Hasil penelitian menyimpulkan bahwa tingkat penerimaan audit system sangat tinggi berdasarkan persepsi pengguna terhadap kemudahan dan kegunaan audit system.

Penelitian lainnya dengan metode TAM dilakukan oleh (Larasati, Probowulan and Syahfrudin, 2019). Penelitian ini bertujuan untuk mengetahui pengaruh persepsi wajib pajak terhadap penerapan $e$-Filing dan kualitas sistem $e$-Filing terhadap kebutuhan pajak. Studi kasus yang digunakan dalam penelitian ini adalah KPP Jember Pratama dengan metode kuantitatif dalam pengambilan datanya. Penelitian ini memperoleh hasil yang menunjukan bahwa persepsi wajib pajak berpengaruh terhadap kepatuhan membayar pajak sedangkan kualitas sistem e-Filing tidak berpengaruh terhadap kepatuhan pajak.

Metode TAM digunakan dalam evaluasi penerapan inventory system dalam penelitian oleh (Christian, 2019). Inventory system yang digunakan sebagai objek kajian penelitian ini adalah PT. DaeIn Tech Indonesia. Penelitian ini bertujuan untuk menemukan faktor penerimaan pengguna terhadap penerapan inventory system baru, sehingga dapat menentukan tingkat keberhasilan sistem tersebut. Hasil penelitian yang diperoleh dari penelitian ini adalah persepsi kemudahan penggunaan sistem berpengaruh positif secara signifikan terhadap persepsi kegunaan dan persepsi kegunaan turut berpengaruh positif terhadap sikap pengguna. Persepsi kemudahan berpengaruh positif signifikan terhadap pengguna sistem, sedangkan persepsi kenyamanan berpengaruh positif signifikan terhadap sikap pengguna. Persepsi kegunaan berpengaruh secara positif signifikan terhadap penerimaan TI dan persepsi pengguna berpengaruh positif signifikan terhadap penerimaan TI.

Evaluasi penerapan dengan analisis TAM juga dilakukan oleh (Krisnawijaya and Dewi, 2019) dengan objek kajian penerapan Undiknas Mobile. Tujuan dari penelitian ini adalah menganalisis intensi pengguna dalam menggunakan Undiknas Mobile hingga pengguna selesai menempuh pendidikannya di Undiknas. Penelitian ini menggunakan metode survei dalam pengambilan datanya dengan melibatkan 263 mahasiswa. Hasil penelitian ini menyertakan bahwa Undiknas Mobile adalah aplikasi yang mudah digunakan dan berguna sehingga intensi pengguna dalam menggunakan aplikasi tersebut terus menerus meningkat. Injuctive norm mempengaruhi intensi pengguna dalam menggunakan aplikasi tersebut.

Penelitian terhadap analisis penerimaan pengguna terhadap suatu sistem juga dilakukan oleh (Thenu and Sitokdana, 2019). Penelitian ini melakukan analisis penerimaan mahasiswa UKSW terhadap aplikasi iSalatiga menggunakan TAM. Studi kasus yang dalam penelitian ini melibatkan dinas perpustakaan dan kearsipan Kota Salatiga yang meluncurkan aplikasi iSalatiga sebagai aplikasi media sosial untuk memudahkan pengguna dalam membaca. Hasil dari penelitian ini menyatakan bahwa penerimaan mahasiswa UKSW mempunyai pengaruh positif pada 3 variabel TAM.

Penelitian oleh (Mintaria and Devitra, 2019) melakukan analisis pada efektivitas aplikasi Sistem Informasi Aset Polri dengan metode TAM pada studi kasus Biro Sarpras Polda Jambi. Peneliti menemukan bahwa Sistem Informasi tidak dimanfaatkan secara maksimal oleh pengguna akhir sehingga dilakukan penelitian pada efektivitas dari sistem tersebut. Pengumpulan data dilakukan terhadap 100 responden untuk mengukur persepsi pengguna dalam menggunakan sistem informasi aset Polri. Hasil penelitian mengemukakan bahwa 
pengguna kurang memahami penggunaan sistem dan tidak memiliki kepercayaan dan minat dalam memanfaatkan aplikasi tersebut, hal ini menyimpulkan bahwa aplikasi sistem informasi aset Polri belum dapat diterapkan secara maksimal.

Proses penerimaan takmir terhadap aplikasi MasjidLink hingga saat ini belum pernah dilakukan oleh penelitian sebelumnya. Penerimaan takmir terhadap aplikasi MasjidLink yang baru diluncurkan perlu diketahui untuk kepentingan pengembangan aplikasi tersebut. Selama ini aspek perilaku mengambil peran yang besar dalam proses penerimaan dan pemanfaatan aplikasi, sehingga dibutuhkan penelitian untuk menentukan aspek perilaku takmir terhadap aplikasi MasjidLink.

Berdasarkan penjelasan yang telah dijabarkan sebelumnya, maka dapat dirumuskan beberapa pertanyaan dalam penelitian ini, yaitu: (1) Aspek penerimaan takmir pada setiap variabelvariabel TAM (2) Saran pengembangan lebih lanjut untuk memaksimalkan penerimaan takmir terhadap MasjidLink.

\section{MasjidLink}

MasjidLink merupakan aplikasi sistem informasi manajemen masjid berbasis android. Tujuan aplikasi ini adalah mewujudkan jejaring antar masjid dengan teknologi informasi. MasjidLink mengambangkan komunitas cyber masjid, pangkalan data masjid, dan pusat informasi masjid. Pengembangan dalam aplikasi bersifat dinamis, interaktif, dan edakwah.

Secara keseluruhan sistem MasjidLink memiliki dua jenis pengguna dengan hak akses yang berbeda. Admin dalam sistem ini menggunakan sistem MasjidLink berbasis web. Hak akses admin adalah mengelola data master MasjidLink dan memberikan akses validitas pada masjid yang terdaftar dalam aplikasi. Aplikasi MasjidLink berbasis android digunakan oleh takmir masjid yang bertindak sebagai pengguna sistem. Takmir masjid dapat mengelola informasi masjid sendiri dan melihat informasi masjid lain.

Analisis kebutuhan fungsional pada sistem MasjidLink dibedakan menurut hak aksesnya. Aplikasi MasjidLink berbasis android mampu menyimpan data pendaftaran takmir dan data masjid secara langsung. Takmir masjid dapat mengelola agenda masjid, data masjidnya, data profil sendiri, dan melihat kegiatan masjid lainnya. Sistem MasjidLink berbasis web digunakan oleh admin sistem. Admin dapat mengelola data pengguna, data berita, pengumuman, jadwal sholat dan memvalidasi masjid. Pengujian penerimaan pengguna menggunakan aplikasi MasjidLink berbasis Android. Implementasi aplikasi MasjidLink untuk takmir masjid ditunjukan pada Gambar 1.
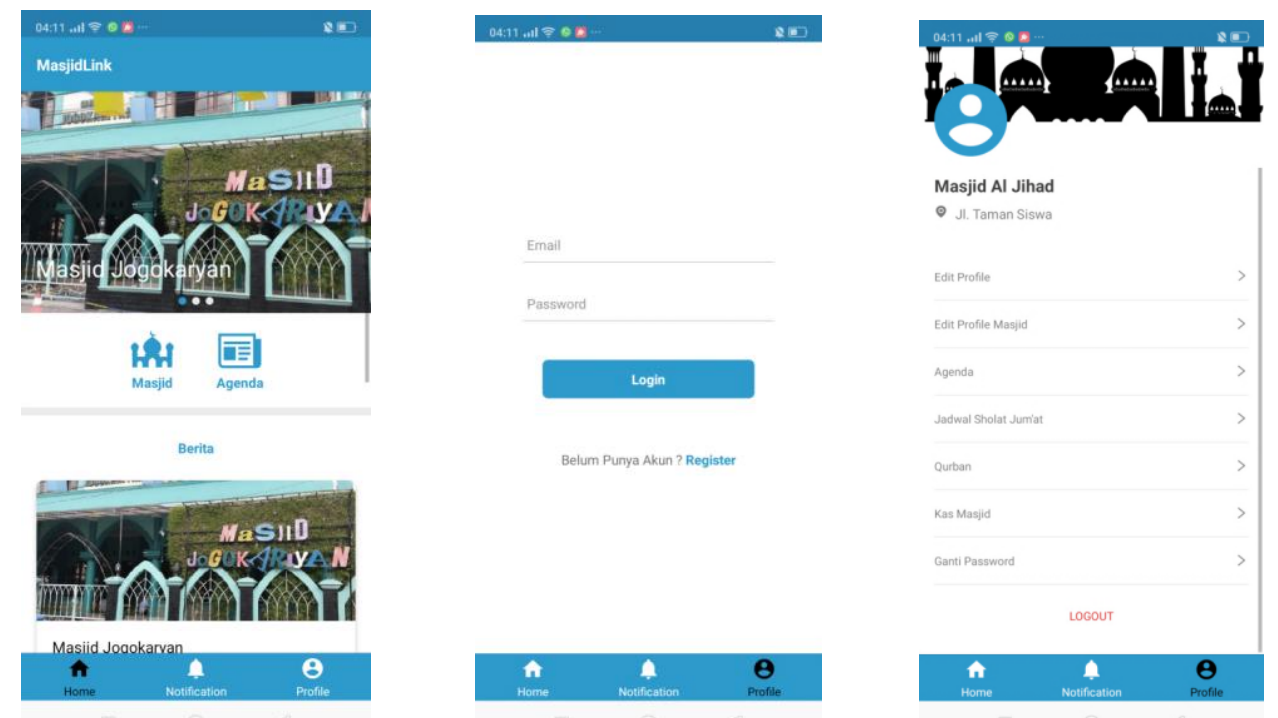

GAMBAR 1. (a)Halaman Dashboard MasjidLink (b)Halaman Login Takmir Masjid (c) Halaman Takmir MasjidLink 
Gambar 1 (a) menunjukan bahwa aplikasi MasjidLink memiliki halaman dasboard yang digunakan sebagai halaman index takmir. Halaman dasboard menampilkan daftar masjid yang terdaftar dalam aplikasi, berita yang dikimkan oleh setiap masjid, dan agenda setiap masjid. Gambar 1 (b) menunjukan halaman yang akan tampil ketika pengguna memilih menu profil. Jika pengguna belum login maka akan tampil halaman login pada menu profil. Takmir diharuskan login terlebih dahulu untuk mendapatkan hak akses takmir pada aplikasi. Takmir yang belum terdaftar bisa melakukan registrasi sebelum proses login. Gambar 1 (c) menunjukan proses yang dapat dilakukan oleh takmir ketika mengakses aplikasi MasjidLink. Halaman takmir masjid memiliki beberapa proses yaitu edit profil takmir, edit profil masjid, mengolah data agenda, mengolah data jadwal, mengolah data kas masjid, mengganti password akun takmir, dan logout.

\section{Technology Acceptance Model (TAM)}

TAM merupakan adaptasi TRA (Theory of Reasoned Action) yang ditemukan oleh Davis pada tahun 1989. Model pendekatan TAM dapat mengetahui dan mempelajari sikap pengguna ketika berinteraksi dengan suatu teknologi informasi. TAM menggambarkan variabel-variabel yang mempengaruhi niat, keinginan, dan sikap pengguna terhadap suatu teknologi informasi (Davis, Bagozzi and Warshaw, 1989).

TAM memiliki beberapa variabel yang mempengaruhinya diantaranya adalah persepsi kemudahan (perceived ease of use), persepsi kebermanfaatan (perceived usefulness), sikap pengguna terhadap penerimaan teknologi (Acceptance of IT). Persepsi seseorang pada suatu hal akan menentukan bagaimana orang tersebut berprilaku dan bersikap. Hal ini diterapkan dalam persepsi pengguna terhadap teknologi informasi, sehingga persepsi akan mempengaruhi bagaimana penerimaan pengguna terhadap suatu teknologi informasi
(Puspita, 2016). Teknik analisis TAM menggunakan teknik analisis deskriptif, yaitu (Napitupulu, 2017) :

\section{Menentukan skor kriterium $(S K)$}

Skor kriterium $(S K)$ merupakan skor ideal yang dicapai dalam penelitian. Cara menghitung skor kriterium adalah dengan Rumus 1.

$\sum S K=$ Skor Maks $I \times n I \times n R$

Keterangan:

$\sum S K \quad$ : Jumlah Skor Kriterium

Skor Maks I : Skor tertinggi setiap indikator pertanyaan

$n I \quad:$ Jumlah indikator pertanyaan

$n R \quad:$ Jumlah responden

\section{Menentukan skor total $(\mathrm{SH})$}

Skor total merupakan total hasil pengumpulan data yang sudah dilakukan dan disimbolkan dengan $\sum S H$.

3. Menentukan besar persentase $(P)$

Besar persentase ditentukan dengan skor kriterium $\left(\sum S K\right)$ dan skor total hasil pengumpulan data $(\Sigma S H)$. Rumus yang digunakan untuk menentukan besar persentase adalah Rumus 2.

$P=\frac{\sum \mathrm{SH} \times 100 \%}{\sum \mathrm{SK}}$

Keterangan :

$P \quad$ : Persentase jawaban responden

$\sum S K \quad:$ Skor kriterium

$\sum S H \quad$ : Skor total pengumpulan data

4. Menentukan rentang hasil

Rentang hasil ditentukan dengan skor kriterium dan persentase yang diperoleh pada langkah sebelumnya, selanjutnya dibandingkan dengan skor hasil pengumpulan data. Rentang hasil yang digunakan terdapat pada Tabel 1 .

TABEL 1 Kategori Jawaban Responden

\begin{tabular}{cc}
\hline Persentase (P) & Kategori Jawaban \\
\hline $0-25 \%$ & Sangat Tidak Setuju \\
$26-50 \%$ & Tidak Setuju \\
$51-75 \%$ & Setuju \\
$76-100 \%$ & Sangat Setuju \\
\hline
\end{tabular}




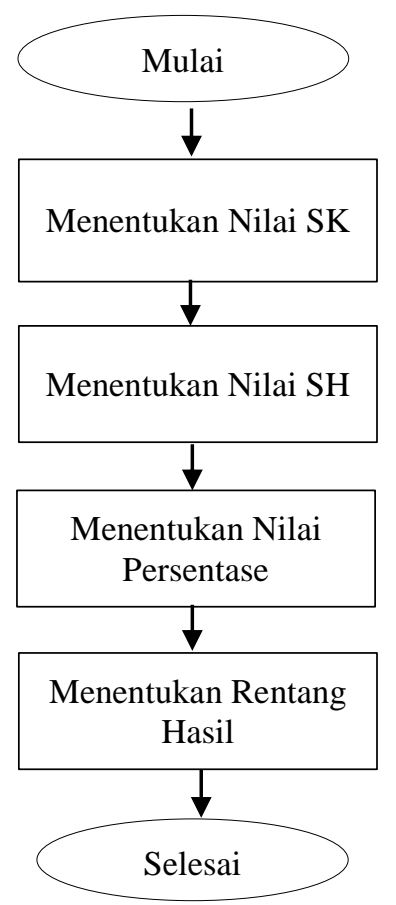

GAMBAR 2 FlowchartMetode TAM

Gambar 2 merupakan langkah-langkah analisis deskriptif pada metode TAM.

\section{Uji Validitas}

Uji validitas menentukan apakah suatu alat ukur yang telah ditentukan dapat mengukur apa yang ingin diukur. Validitas tes atau uji validitas instrumen merupakan alat ukur pada derajat kecermatan instrumen penelitian. (Nisfiannoor, 2009). Uji validitas mengukur sah atau valid tidaknya suatu variabel dalam kuesioner. Pengukuran uji validitas dilakukan dengan tiga cara yaitu: melakukan korelasi antara skor variabel pertanyaan dengan total skor konstruk, menghitung korelasi skor setiap variabel pertanyaan dengan total skor, dan menggunakan analisis faktor yang menguji variabel pertanyaan pada kuesioner untuk mengkonfirmasi sebuah konstruk. (Sunyoto, 2007). Instrumen penelitian dikatakan valid apabila nilai corrected Item-Total Correlation lebih besar dari nilai signifikan $r$ tabel (Supriyadi, 2014).

\section{Uji Reliabilitas}

Uji Reliabilitas digunakan sebagai alat ukur pada suatu indikator atau variabel kuesioner. Indikator yang reliabel atau handal merupakan indikator yang konsisten. Pengukuran reliabilitas dapat dilakukan dengan dua cara, yaitu repeated measure (pengukuran ulang) dan one shot (pengukuran sekali). Pengukuran ulang menyatakan suatu variabel memiliki nilai yang reliabel atau handal apabila memiliki jawaban yang sama dengan alternatif jawaban yang telah ditentukan. Tahapan pengukuran sekali mengukur korelasi pada skor jawaban dengan sejumlah pertanyaan yang sama dengan bantuan program SPSS (Statistical Program for Society Science). Pengujian reliabilitas pada SPSS menggunakan fungsi Cronbatch Alpha ( $\alpha$ ) (Sunyoto, 2007). Suatu variabel pada kuesioner dapat dikatakan handal atau reliabel, jika nilai cronbatch alpha di atas 0.7. Hasil uji reliabilitas menggambarkan tingkat kepercayaan suatu instrumen penelitian dengan menyatakan bahwa hasil pengukuran yang didapatkan merupakan ukuran yang benar setelah dilakukan pengukuran (Supriyadi, 2014).

\section{METODE PENELITIAN}

Metode penelitian yang digunakan adalah metode kuantitatif, yaitu dengan menggunkan kuesioner sebagai alat untuk mengumpulkan data yang terdiri dari penyataan responden dalam bentuk data. Kuesioner terdiri dari instrumen TAM untuk menentukan aspek-aspek penerimaan takmir terhadap MasjidLink. Tahapan penelitian ditunjukan pada Gambar 3. 


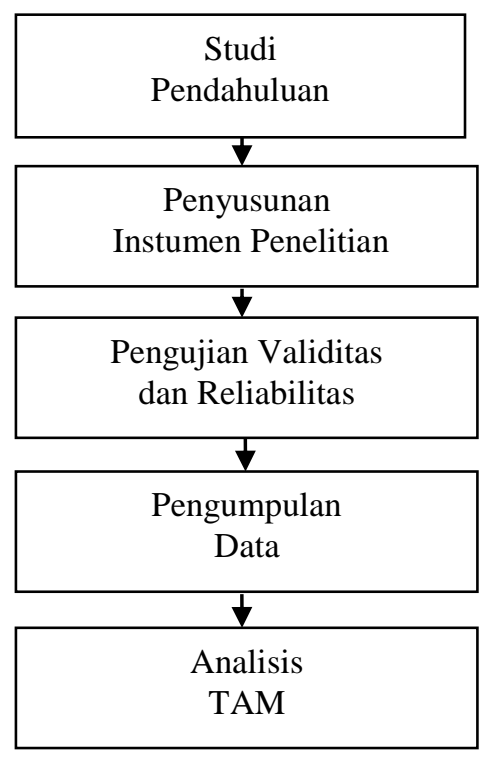

GAMBAR 3 Tahapan Penelitian

\section{Studi Pendahuluan}

Metode penelitian dalam penelitian ini menggunakan 5 tahapan yang dimulai dengan studi pendahuluan. Tahap studi pendahuluan dilakukan dengan menemukan, mempelajari, dan memahami beragam referensi penelitian, yaitu buku, jurnal ilmiah, dan penelitian terdahulu yang masih memiliki kaitan dengan objek penelitian.

\section{Penyusunan Instrumen Penelitian}

Tahap selanjutnya adalah tahap penyusunan instrumen penelitian. Tahapan ini dilakukan dengan menentukan instrumen yang akan digunakan pada kuesioner yaitu disusun dengan pendekatan TAM. Instrumen penelitian ini terdiri dari 21 indikator dalam tiga variabel TAM yaitu variabel kemudahan (perceived ease of use), variabel kebermanfaatan (perceived usefulness), dan variabel penerimaan (Acceptance of IT).

\section{Pengujian Validitas dan Reliabilitas}

Tahap ketiga merupakan tahap pengujian validitas dan reliablitas. Pengujian validitas digunakan untuk mengukur tingkat validitas dan kelayakan instrumen-instrumen kuesioner penelitian. Pengujian reliabilitas pada penelitian ini bertujuan untuk mengukur tingkat kehandalan instrumen dalam kuesioner penelitian.

\section{Pengumpulan Data}

Tahap berikutnya adalah pengumpulan data. Penelitian ini menggunakan metode kuantitatif. Penelitian ini menggunakan survei yang melibatkan takmir masjid di Daerah Istimewa Yogyakarta. Kuesioner menggunakan layanan google form berbasis daring. Penilaian responden menggunakan skala linkert, dimana nilai (1) adalah sangat tidak setuju, nilai (2) yaitu tidak setuju, (3) bernilai netral, (4) merupakan nilai setuju, dan terakhir (5) berarti sangat setuju.

\section{Analisis TAM}

Tahap berikutnya adalah pengumpulan data. Penelitian ini menggunakan metode kuantitatif. Penelitian ini menggunakan survei yang melibatkan takmir masjid di Daerah Istimewa Yogyakarta. Kuesioner menggunakan layanan google form berbasis daring. Penilaian responden menggunakan skala linkert, dimana nilai (1) adalah sangat tidak setuju, nilai (2) yaitu tidak setuju, (3) bernilai netral, (4) merupakan nilai setuju, dan terakhir (5) berarti sangat setuju.

Data yang telah dikumpulkan pada tahap sebelumnya akan digunakan pada tahap ini, yaitu tahap analisis TAM. Hasil analisis TAM dapat digunakan oleh peneliti untuk menemukan aspek penerimaan takmir pada setiap variabel TAM. Nilai pada setiap aspek dapat berguna untuk saran pengembangan MasjidLink pada masa yang akan datang. 


\section{HASIL DAN PEMBAHASAN}

\section{Instrumen Penelitian}

Instrumen penelitian menggunakan indikatorindikator TAM. Instrumen-instrumen yang diterapkan pada kuesioner penelitian berjumlah 21 indikator yang terdiri dari variabel kemudahan, variabel kebermanfaatan, dan variabel penerimaan teknologi informasi. Instrumen penelitian dalam penelitian ini ditunjukan oleh Tabel 2. Instrumen penelitian pada Tabel 2 memuat indikator TAM yang telah disesuaikan dengan obyek penelitian yaitu variabel penerimaan takmir terhadap MasjidLink. Instrumen yang telah ditentukan akan digunakan dalam kuesioner penelitian. Kuesioner yang digunakan berbasis daring dengan layanan google form. Kuesioner penelitian memuat pertanyaan data diri responden. Data responden berguna dalam memetakan data secara demografis. Instrumen dalam kuesioner akan dilakukan pengolahan data dengan analisis TAM. Pengujian instrumen penelitian menggunakan uji validitas dan reliabilitas.

\section{Hasil Uji Validitas}

Uji validitas instrumen pada penelitian ini menggunakan tools SPSS. Pengujian dilakukan dengan menghitung korelasi antara nilai masing-masing instrumen penelitian dengan total nilai instrumen suatu variabel.

Nilai total instrumen pada variabel yang sama dihitung terlebih dahulu sebelum melakukan uji validitas. Nilai total akan digunakan dalam uji validitas dengan menggunakan SPSS. Jika nilai standar koefisien korelasi adalah 0.5 atau lebih maka data dinyatakan valid (Sunyoto, 2007). Hasil uji validitas pada penelitian ini terdapat pada Tabel 3.

TABEL 1 Instrumen Penelitian

\begin{tabular}{|c|c|c|}
\hline Variabel & Kode & Indikator \\
\hline \multirow{7}{*}{$\begin{array}{l}\text { Kemudahan } \\
\text { (Perceived Ease } \\
\text { of Use) }\end{array}$} & PEU1 & Saya mudah mempelajari cara menggunakan Aplikasi Takmir MasjidLink \\
\hline & PEU2 & Saya terampil dalam menggunakan Aplikasi Takmir MasjidLink dengan mudah \\
\hline & PEU3 & $\begin{array}{l}\text { Saya dapat menggunakan Aplikasi Takmir MasjidLink untuk mempermudah } \\
\text { pekerjaan saya }\end{array}$ \\
\hline & PEU4 & Saya dapat berinteraksi dengan Aplikasi Takmir MasjidLink dengan jelas \\
\hline & PEU5 & $\begin{array}{l}\text { Saya dapat memahami dengan baik cara berinteraksi dengan Aplikasi Takmir } \\
\text { MasjidLink }\end{array}$ \\
\hline & PEU6 & $\begin{array}{l}\text { Saya beranggapan bahwa Aplikasi Takmir MasjidLink merupakan program yang } \\
\text { fleksibel }\end{array}$ \\
\hline & PEU7 & Saya dapat menggunakan Aplikasi Takmir MasjidLink dengan mudah \\
\hline \multirow{7}{*}{$\begin{array}{l}\text { Kebermanfaatan } \\
\text { (Perceived } \\
\text { Usefulness) }\end{array}$} & POU1 & $\begin{array}{l}\text { Saya mampu mengerjakan pekerjaan lebih cepat dengan Aplikasi Takmir } \\
\text { MasjidLink }\end{array}$ \\
\hline & POU2 & $\begin{array}{l}\text { Saya beranggapan bahwa pekerjaan saya menjadi lebih mudah dengan } \\
\text { menggunakan Aplikasi Takmir MasjidLink }\end{array}$ \\
\hline & POU3 & $\begin{array}{l}\text { Saya dapat meningkatkan produktivitas kerja dengan Aplikasi Takmir } \\
\text { MasjidLink }\end{array}$ \\
\hline & POU4 & Saya dapat meningkatkan efektivitas kerja dengan Aplikasi Takmir MasjidLink \\
\hline & POU5 & Saya beranggapan bahwa Aplikasi Takmir MasjidLink dapat berguna bagi saya \\
\hline & POU6 & $\begin{array}{l}\text { Saya terbantu dengan mendapatkan informasi dari masjid lain melalui Aplikasi } \\
\text { Takmir MasjidLink }\end{array}$ \\
\hline & POU7 & $\begin{array}{l}\text { Saya terbantu dengan mendapatkan informasi kerja sama antar masjid lain } \\
\text { melalui Aplikasi Takmir MasjidLink }\end{array}$ \\
\hline \multirow{7}{*}{$\begin{array}{l}\text { Penerimaan } \\
\text { (Acceptance of } \\
\text { IT) }\end{array}$} & AOT1 & Saya nyaman menggunakan Aplikasi Takmir MasjidLink \\
\hline & AOT2 & Saya menikmati penggunaan Aplikasi Takmir MasjidLink \\
\hline & AOT3 & Saya beranggapan bahwa Aplikasi Takmir MasjidLink tidak membosankan \\
\hline & AOT4 & Aplikasi Takmir MasjidLink menyediakan informasi yang saya butuhkan \\
\hline & AOT5 & $\begin{array}{l}\text { Saya bekerja dengan mengacu pada informasi yang disediakan Aplikasi Takmir } \\
\text { MasjidLink }\end{array}$ \\
\hline & AOT6 & Aplikasi Takmir MasjidLink menyediakan informasi yang akurat \\
\hline & AOT7 & $\begin{array}{l}\text { Saya menggunakan Aplikasi Takmir MasjidLink dalam durasi waktu yang } \\
\text { panjang }\end{array}$ \\
\hline
\end{tabular}


TABEL 2 Hasil Uji Validitas

\begin{tabular}{lcc}
\hline Kode & $\begin{array}{r}\text { Corrected item-total } \\
\text { correlation }\end{array}$ & Keterangan \\
\hline PEU1 & 0.877 & VALID \\
PEU2 & 0.908 & VALID \\
PEU3 & 0.786 & VALID \\
PEU4 & 0.877 & VALID \\
PEU5 & 0.879 & VALID \\
PEU6 & 0.770 & VALID \\
PEU7 & 0.885 & VALID \\
POU1 & 0.841 & VALID \\
POU2 & 0.874 & VALID \\
POU3 & 0.874 & VALID \\
POU4 & 0.831 & VALID \\
POU5 & 0.798 & VALID \\
POU6 & 0.807 & VALID \\
POU7 & 0.791 & VALID \\
AOT1 & 0.895 & VALID \\
AOT2 & 0.901 & VALID \\
AOT3 & 0.874 & VALID \\
AOT4 & 0.791 & VALID \\
AOT5 & 0.842 & VALID \\
AOT6 & 0.841 & VALID \\
AOT7 & 0.813 & VALID \\
\hline
\end{tabular}

Tabel 3 menunjukan seluruh instrumen penelitian memiliki nilai lebih dari 0.5 sehingga dapat dinyatakan valid.

\section{Hasil Uji Reliabilitas}

Pengujian reliabilitas dalam penelitian ini menentukan kehandalan atau reliabilitas instrumen penelitian. SPSS digunakan sebagai alat untuk membantu perhitungan uji reliabilitas. Uji hipotesis menggunakan perhitungan regresi berganda.
Nilai untuk menentukan tingkat reliabilitas adalah nilai cronbatch alpha. Nilai cronbatch alpha 0.7 atau lebih menyatakan bahwa instrumen penelitian memiliki nilai reliabel atau handal (Supriyadi, 2014). Hasil uji reliabilitas pada penelitian ini ditunjukan pada Tabel 4. Variabel TAM dalam penelitian ini memiliki nilai cronbatch alpha lebih dari 0.7 berdasarkan Tabel 4, sehingga semua variabel penelitian ini dapat dikatakan handal atau reliabel.

TABEL 3 Hasil Uji Reliabilitas

\begin{tabular}{lcc}
\hline Variabel & Cronbatch Alpha & Keterangan \\
\hline PEU & 0.939 & Reliabel \\
\hline POU & 0.925 & Reliabel \\
\hline AOT & 0.934 & Reliabel \\
\hline
\end{tabular}

TABEL 4 Deskripsi Penelitian TAM

\begin{tabular}{lllll}
\hline Variabel & Min & Maks & Mean & Std. Deviation \\
\hline PEU & 1 & 5 & 3.634 & 0.893 \\
\hline POU & 1 & 5 & 3.675 & 0.821 \\
\hline AOT & 1 & 5 & 3.483 & 0.859
\end{tabular}




\section{Analisis TAM}

\section{a. Deskripsi Penelitian TAM}

Data penelitian ini diperoleh setelah mengadakan pelatihan dan pendampingan aplikasi MasjidLink. Kuesioner penelitian yang diedarkan mendapatkan data sejumlah 125 responden.

Informasi demografis responden yang diperoleh dari data yang terkumpul meliputi jenis kelamin dan umur. Jenis kelamin responden menunjukan bahwa responden lakilaki lebih banyak dibanding perempuan dengan nilai persentase laki-laki adalah $63.5 \%$ dan perempuan $36.5 \%$. Informasi demografis umur responden menunjukan bahwa umur 21 sampai 25 adalah umur yang dominan dalam data dengan nilai $68.3 \%$, responden dengan umur lebih dari 40 tahun $14.3 \%$, responden dengan umur lebih dari 36 sampai 40 tahun $8.7 \%$. Responden dengan data terendah pada informasi demografis umur terdapat pada umur lebih dari 40 tahun dengan 5.6\%, 31 sampai 35 tahun dengan $2.4 \%$, dan terendah dengan $0.8 \%$ pada umur 26 sampai 30 tahun.

Data jawaban responden atas pertanyaan dalam kuesioner berupa hasil deskripsi penelitian yang ditunjukan oleh Tabel 5. Berdasarkan deskripsi penelitian TAM pada Tabel 5 dapat diketahui persepsi pengguna berdasarkan variabel kemudahan (PEU), kebermanfaatan (POU), dan penerimaan (AOT). Variabel kemudahan (PEU) pada penelitian ini menggunakan 7 indikator pertanyaan. Nilai minimum variabel ini ditunjukan pada Tabel 4 yaitu sebesar 1. Nilai 1 merupakan nilai yang menyatakan sangat tidak setuju. Nilai maksimum variabel PEU sebesar 5. Hal ini menyatakan bahwa responden sangat setuju terhadap pernyataan yang diajukan. Nilai ratarata variabel PEU adalah 3.634 yang berarti sejumlah rata-rata responden menyatakan setuju terhadap pernyataan yang diajukan. Pernyataan setuju responden menunjukan bahwa responden memiliki persepsi bahwa MasjidLink dapat memudahkan ketika digunakan.
Variabel kebermanfaatan (POU) memiliki 7 indikator pertanyaan. Berdasarkan Tabel 4, variabel POU memiliki nilai minimum sebesar 1 yang menyatakan sangat tidak setuju. Nilai maksimum variabel POU sebesar 5. Hal ini menyatakan bahwa responden sangat setuju terhadap pernyataan yang diajukan. Nilai ratarata variabel POU adalah 3.675 yang berarti sejumlah rata-rata responden menyatakan setuju terhadap pernyataan yang diajukan. Pernyataan setuju responden menunjukan bahwa responden memiliki persepsi bahwa MasjidLink memberikan manfaat pada mengelola data masjid dan melihat informasi masjid.

Variabel penerimaan (AOT) memiliki 7 indikator pertanyaan. Berdasarkan Tabel 4, variabel AOT memiliki nilai minimum sebesar 1 yang menyatakan sangat tidak setuju. Nilai maksimum variabel AOT sebesar 5. Hal ini menyatakan bahwa responden sangat setuju terhadap pernyataan penerimaan pada MasjidLink. Nilai rata-rata variabel AOT adalah 3.483 hal ini menyatakan bahwa sejumlah rata-rata responden setuju pada penerimaan MasjidLink.

\section{b. Statistik Deskriptif}

Analisa statistik deskriptif bertujuan mengetahui hasil kuesioner pada tiga variabel. Tabel 6 menunjukan hasil statistika deskriptif pada penelitian TAM MasjidLink.

Berdasarkan Tabel 5 dan Tabel 6 dapat diketahui hasil distribusi persentase jawaban responden. Jumlah pertanyaan pada setiap variabel dihitung berdasarkan indikator setiap variabel. Nilai $\sum$ SK diperoleh dari perkalian nilai maksimum pada variabel, jumlah pertanyaan, dan jumlah responden. Sebagai contoh, nilai $\sum$ SK variabel kemudahan (PEU)

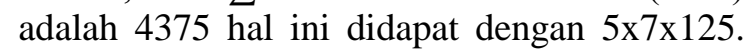
Nilai $\sum$ SH diperoleh dari jumlah total nilai dari semua data responden dari setiap variabel TAM. Besar $\mathrm{P}$ atau persentase diperoleh dengan membagikan nilai $\sum \mathrm{SK}$ dengan $\sum \mathrm{SH}$ dikali $100 \%$.

TABEL 5 Hasil Statistika Deskriptif

\begin{tabular}{ccccc}
\hline Variabel & nI & $\sum$ SK & $\sum$ SH & P \\
\hline PEU & 7 & 4375 & 3180 & $72.68 \%$ \\
\hline POU & 7 & 4375 & 3155 & $72.11 \%$ \\
\hline AOT & 7 & 4375 & 3120 & $71.31 \%$ \\
\hline
\end{tabular}


Secara keseluruhan, jawaban responden pada variabel kemudahan (PEU) termasuk dalam kategori setuju dengan nilai persentase 72.68\%. Persepsi takmir dapat dinyatakan menganggap bahwa aplikasi MasjidLink mudah untuk digunakan dalam mengelola data masjid dan melihat informasi masjid.

Nilai persentase pada variabel kebermanfaatan (POU) adalah $72.11 \%$. Berdasarkan hal ini dapat dinyatakan bahwa takmir menganggap aplikasi MasjidLink dapat bermanfaat dalam proses memanajemen data masjid dan memperoleh informasi masjid lainnya.

Nilai persentase pada variabel penerimaan (AOT) adalah $71.31 \%$. Berdasarkan hal ini dapat dinyatakan bahwa penerimaan takmir masjid terhadap aplikasi MasjidLink cukup tinggi.

\section{KESIMPULAN}

Berdasarkan penelitian pada penerapan TAM dalam pengujian model penerimaan aplikasi MasjidLink, dapat diambil kesimpulan persepsi kemudahan pengguna (perceived ease of use) memiliki nilai persentase $72.68 \%$ yang menyatakan bahwa takmir masjid setuju dengan kemudahan penggunaan aplikasi MasjidLink. Persepsi kebermanfaatan (perceived of usefulness) memiliki nilai persentase $72.11 \%$ yang menyatakan bahwa takmir masjid setuju dengan kebermanfaatan aplikasi MasjidLink. Persepsi penerimaan (acceptance of $T I$ ) memiliki nilai persentase $71.31 \%$ yang menyatakan bahwa takmir masjid setuju dengan penerimaan aplikasi MasjidLink. Hasil analisis statistik deskriptif pada TAM memiliki variabel dengan nilai persentase paling kecil yaitu persentase penerimaan MasjidLink dengan nilai $71.31 \%$. Hal ini dapat digunakan untuk meningkatkan pengembangan MasjidLink dengan berfokus pada penerimaan aplikasi MasjidLink.

\section{UCAPAN TERIMA KASIH}

Kami mengucapkan terima kasih kepada Direktur Pendidikan Tinggi Islam atas pemberian Bantuan Pengabdian Masyarakat Berbasis Riset Unggulan Nasional Direktorat Pendidikan Tinggi Keagamaan Islam Tahun 2019.
Bantuan ini berdasar Keputusan Pejabat Pembuat Komitmen Direktorat Pendidikan Tinggi Keagamaan Islam Direktorat Jenderal Pendidikan Islam Kementerian Agama Nomor 1954 Tahun 2019 Tanggal 08 April 2019 Tentang Penerima Bantuan Pengabdian Masyarakat Berbasis Riset Unggulan Nasional Tahun Anggaran 2019.

\section{DAFTAR PUSTAKA}

Alvin and Kurniawati. (2019). Analisis Penerimaan Audit Software Bagi Auditor Eksternal Dengan Menggunakan Pendekatan Technology Acceptance Model ( TAM ). Balance Vocation Accounting Journal. 3(2), pp. $1-17$.

Christian, A. (2019). Evaluasi Penerapan Inventory System Menggunakan Technology Acceptance Model ( TAM ). Jurnal PILAR Nusa Mandiri, 15(1), pp. 119-124.

Davis, F. D., Bagozzi, R. P. dan Warshaw, P. R. (1989). User Acceptance of Computer Technology: A Comparison of Two Theoretical Models User. Management Science, 35(8). doi: 10.1287/mnsc.35.8.982.

Hermawan, R. (2019). Penerapan Aplikasi Parental Control Screen Time dalam Penggunaan Smartphone bagi Anakanak. Jurnal Susunan Artikel Pendidikan (SAP), 4(1).

Krisnawijaya, N. N. K. and Dewi, I. G. A. A. P. (2019). Evaluasi Penerapan Undiknas Mobile: Analisis Technology Acceptance Model. Science and Infromation Technology (SINTECH) Journal, 2(2), pp. 71-80.

Larasati, A. W., Probowulan, D. and Syahfrudin, A. (2019). Pengaruh Persepsi Wajib Pajak atas Penerapan E-Filing dan Persepsi Wajib Pajak atas Kualitas Sistem E-Filing Terhadap Kepatuhan Pajak. COSTING:Journal of Economic, Business and Accounting, 3(1), pp. 208-216.

Mintaria and Devitra, J. (2019). Analisis Efektivitas Aplikasi Sistem Informasi Aset Polri Menggunakan Metode Technology Accaptance Model pada 
Biro Sarpras Polda Jambi. Jurnal Manajemen Sistem Informasi, 4(2), pp. 216-228.

Napitupulu, D. (2017). Kajian Penerimaan ELearning dengan Pendekatan TAM Study of E-Learning Acceptance Based on TAM Approach. Prosiding Seminar Nasional Multidisiplin Ilmu.

Nisfiannoor, M. (2009). Pendekatan Statistika Modern untuk Ilmu Sosial. Edited by A. N. Dini. Jakarta: Salemba Humanika.

Puspita, M. C. (2016). Pengujian Technology Acceptance Model Terhadap Sikap Adopsi Internet Banking di Universitas Lampung. Universitas Lampung.

Ratri, S. M. (2016). Analisis Faktor-faktor yang Mempengaruhi Penggunaan ELearning Moodle oleh Guru SMK Negeri 2 Yogyakarta dengan Pendekatan Technology Acceptance Model (TAM). Universitas Negeri Yogyakarta.

Sunyoto, D. (2007). Analisis Regresi dan Korelasi Bivariat Ringkasan dan Kasus. Yogyakarta: Amara Books.

Supriyadi, E. (2014). SPSS + Amos. Jakarta: IN MEDIA.

Thenu, E. P. and Sitokdana, M. N. N. (2019). Analisis Penerimaan Mahasiswa UKSW Terhadap Penggunaan iSalatiga Menggunakan Technology Acceptance Model ( Studi Kasus: Dinas Perpustakaan dan Kearsipan Kota Salatiga ). Jurnal Sebatik, 23(2), pp. 324-329.

PENULIS:

Agus Mulyanto

Program Studi Teknik Informatika, Fakultas Sains dan Teknologi, Universitas Islam Negeri Sunan Kalijaga, Kota Yogyakarta.

Email: agus.mulyanto@uin-suka.ac.id

\section{Sumarsono}

Program Studi Teknik Informatika, Fakultas Sains dan Teknologi, Universitas Islam Negeri Sunan Kalijaga, Kota Yogyakarta.

\section{Thaqibul Fikri Niyartama}

Program Studi Matematika, Fakultas Sains dan Teknologi, Universitas Islam Negeri Sunan Kalijaga, Kota Yogyakarta.

Annisa Khodista Syaka

Program Studi Magister Teknologi Informasi, Departemen Teknik Elektro dan Teknologi Informasi, Fakultas Teknik, Universitas Gadjah Mada, Kota Yogyakarta. 